\title{
A Study on the Evaluation of ICT development level in University Administrative Departments in China
}

\author{
Min Chen ${ }^{1, a}$, Chao Fan ${ }^{2, b}$, Di Wu ${ }^{3, c^{*}}$ \\ ${ }^{1}$ National Engineering Research Center for E-Learning Central China Normal University, \\ Wuhan, 430079, China \\ ${ }^{2}$ National Engineering Research Center for E-Learning Central China Normal University, \\ Wuhan, 430079, China \\ ${ }^{3}$ National Engineering Research Center for E-Learning Central China Normal University, \\ Wuhan, 430079, China

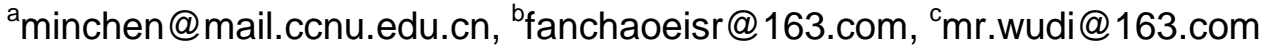

\begin{abstract}
Keywords: Evaluation model of ICT development level; evaluation index system of ICT development level; development of ICT in higher education
\end{abstract}

\begin{abstract}
The development of ICT in administrative department is an important part of ICT application in higher education. The evaluation of ICT development level in each administrative department of university is an effective way to understand and promote the development of ICT in education, which has great significance to make a detailed understanding of the characteristics and problems and strengthen the construction of ICT development of universities. However, the majority of ICT development level evaluation makes the management informatization as a part of the university informatization evaluation, and the contents of the evaluation focus on university level. It is difficult to evaluate the ICT development level in administrative departments accurately and appropriately. In order to promote the construction and development of management informatization in higher education, this study proposed an evaluation model and an evaluation index system for the ICT development in university administrative departments. By using the model and the index system, the study carried out a case study to evaluated and analyzed the ICT development level of the administrative departments of a university in China, the result showed that the degree of informatization of each department of the university was often seriously polarized, the development level of ICT in the departments for student services and propaganda(such as Propaganda Department) was better than in the comprehensive management departments(such as Organization Department and Archive), the management business process was significantly related to the shared data ratio and the data quality. Data construction is the important prerequisite for the realizing informatization of management business process.
\end{abstract}

\section{Introduction}

The rapid development of ICT has brought a revolutionary impact on the development of education [1]. Using the education informatization to promote the education modernization and realizing the leaping development of education is an important strategic choice of the educational development and reform. Since 21st Century, the speed of the development of ICT in China has been unprecedented. And the government's attention to the educational informatization has reached an unprecedented height [2]. As an important part of the national economy and society informatization, education informatization is in an important strategic stage which is continuous advancement and further development [3].

As an important part of education informatization, the higher education informatization has a positive impact on promoting the reform and development of the whole education [4]. In recent years, higher education management informatization has been regarded as an important aspect of

\footnotetext{
* Di Wu is the corresponding author.
} 
the construction and development of higher education by the government and researchers of China [5]. University management involves many aspects, which consists of different administrative and service departments, and due to different properties and responsibilities, the interaction between different administrative departments with ICT development level is not similar. In order to promote the construction and development of university management informatization, we not only need to pay attention to the management informatization from the level of the whole school, but also need to focus on the ICT development level in each management department, and then to promote the rational allocation of resources in university and to realize comprehensive and healthy development of university informatization. So this study tried to construct an evaluation model and an index system to help understanding the ICT development level of the university administrative departments in China, and carried out a practice to evaluate and analyze the ICT development level of the administrative departments of a university in China by using the model and the index system, and also gave some suggestions to the university.

\section{Relevant works}

"ICT Promoting Development Partnership" was composed of the International Telecommunication Union (ITU), United Nations Forum on Trade and Development (UNCTAD), the United Nations Educational Scientific and Culture Organization (UNESCO), the World Bank and other more than 10 institutions. They succeeded in the league in 2005 and began to formulate and issue the "ICT core indexes" [6]. In 2010 edition of the "ICT core indexes report" of the "ICT core indexes in education", nine indexes of education ICT were listed [7]. These indexes mainly focused on the network, equipment and other infrastructure construction, ICT personnel training, as well as the number of teachers with ICT capabilities, but the evaluation of education management informatization was left out.

The Campus Computing Project (CCP) [8] was one of the most authoritative research projects in the field of higher education informatization in the United States. The research projects always selected 600 to 800 Universities in the United States each year to conduct sample surveies and interviews. They used the integration of qualitative and quantitative methods to analyze the development and application of campus informatization, and regularly published the report. The project focused on ICT development planning, funding, teaching application, teacher training and other aspects of the situation, but the university management informatization evaluation was less mentioned.

American higher education informatization professional organizations (EDUCAUSE) was a non-profit professional association with the mission of using ICT to promote the development of higher education reasonably, and served for universities, higher education institutions and information technology companies. It was formed by the professional organization named College and University Systems Exchange (CAUSE) which engaged in college management informatization in administrative management and Interuniversity Communications Council (EDUCOM), which is committed to the using of computer technology to transform the university teaching and the scientific research system. It is the largest higher education informatization professional organizations around the world. American higher education informatization annual top ten IT issues released by EDUCAUSE not only promoted the sustained development of informatization of higher education in the United States, and also provided abundant resource and important ideas to the development of higher education informatization in the world [9]. From the point of the core issues released in 2000 to 2016 annual top ten IT issues, the core issues of higher education management informatization involved in funding, infrastructure, information security, IT governance and leadership, information strategy, business reform and efficiency, data management, the construction and maintenance of management system [10][11].

In addition, EDUCAUSE also collaborated with the American Association of Collegiate Registrars and Admissions Officers (AACRAO) and The National Association for College Admission Counseling (NACAC) to launch an index system named The Student Guide to Evaluating Information Technology on Campus to evaluate the informatization in universities and 
colleges in the United States [12]. The index system evaluated the informatization level in universities and colleges from the four aspects including academic experience, administrative experience, student life, services and fees. The index system has been cited by many American colleges and universities because of the strong operational performance [13].But this index system was mainly from the demand of students, and the university management informatization was only reflected in the aspects which students can perceive, so the evaluation of university management information was one-sided.

The Asian Campus Computing Survey (ACCS) was sponsored by the Hong Kong University, and participated by many institutions in the United States and Japan. It was one of the most authoritative information evaluation research projects in Asia. ACCS investigated the informatization construction and development of more than 1000 universities in Asia by questionnaire to understand the latest news and information of the informatization construction and development in Asian countries. The main investigational directions included: planning, management and policy, teaching and learning, services, facilities and resources, budget, development trends of informatization [14] [15].

In recent years, there has been more and more scholars conduct researches from different angles on the evaluation model and index system of higher education informatization in China. For example, Zhang, et al. designed the basic framework of index system of higher education informatization from the pivotal success factors which influenced the strategic development goal. The content of the framework included strategic position, infrastructure, application, information resources, human resources, organization and management six first-level indexes [16].An, et al. constructed the higher education ICT evaluation index framework from the angle of the informatization satus, the framework evaluated the informatization level from four first-level indexes of organizational system, policy system, technical support and training system[17].Qin, Xu and Su designed the university informatization evaluation target system which the seven first-level indexes included informatization strategy, infrastructure, information resources, information application system, information talents and education, security management services and information policy, and the system based on the national informatization index system and refered to the Chinese enterprise informatization indexes [18].Jiang, etc. evaluated and analysed the development of informatization in colleges and universities from infrastructure, digital resources, information system, standard specification, management system and operation mechanism [19]. Duan and Liu constructed the evaluation model of higher education informatization according to the higher education informatization evaluation index construction principle. Combining with the existing domestic and foreign research, they established a set of evaluation index system from the five aspects including strategic position, infrastructure, informatization application system, information resource and human resources and so on [20].Wu, et al. constructed a performance evaluation meta model from the business and informatization on business support, and constructed an education informatization performance evaluation index system from infrastructure, human resources, information system and data, business activities and processes, user effect, career development [21].

From the existing research, most of university ICT evaluation mainly made management informatization as a part of the higher education informatization evaluation from the angle of the overall development of the university, and the evaluation contents were also designed in the university level, so it was difficult to evaluate the ICT level of all kinds of departments directly.

\section{Evaluation model and index system of ICT development level in university administrative departments}

Evaluation Model of ICT development level in university administrative departments.

AS a micro education informatization evaluation, this study based on the university administrative department informatization evaluation. The study constructed the evaluation model of ICT development level in university administrative departments from the perspective of using information technology to promote the development of management informatization, as shown in 
Figure 1. The model consisted of six elements, including system and website, data construction, human resource, planning and management, information security, business process and information release. These six elements were divided to three levels including foundation support, operation guarantee and sector development. Business process informatization is the core of ICT development in university management departments, and it is also an important aspect to promote the development of the management departments. Developing business process informatization needs the support of system, human resource and data. And the sustainable development of business process informatization needs the scientific and reasonable planning, management and information security as the prerequisite. Therefore, the relationships of the three levels are: foundation support provides the basic support for business process and information release, and it is also the object and basis of the operation guarantee; operation guarantee provides many security guarantee for the continuous and smooth development of business process and information release. Under the supports of foundation support and operation guarantee, it realizes the informatization of business process and information release finally.

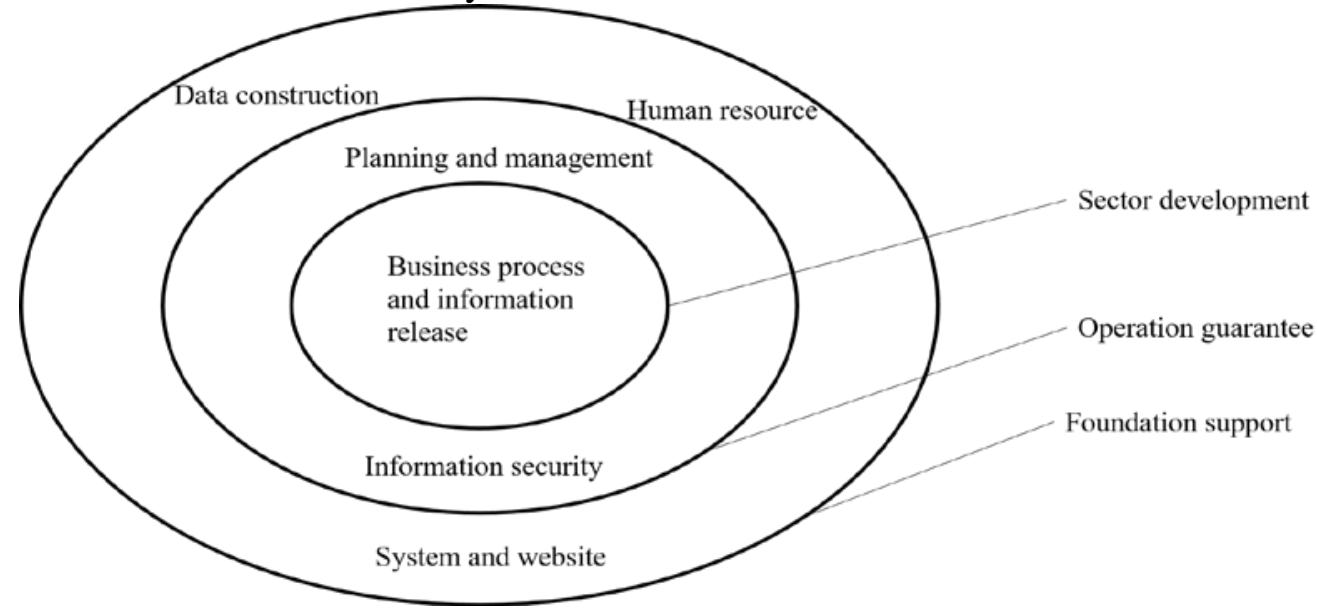

Fig 1. Evaluation Model of ICT development level in university administrative departments

Evaluation index system of ICT development level in university administrative departments.

Based on the above evaluation model, the study established the first-level indexes of the index system. And then we drafted second-level indexes and third-level indexes by referring to the relevant theories, many previous research results and successful cases. Finally, the study organized a number of expert seminars to ensure the accuracy and maneuverability of the index system, and corrected the index system repeatedly according to the suggestions from the experts. Tab 1 shows the evaluation index system. Due to limited space, here we only showed the first-level indexes and second-level indexes.

Tab 1. Evaluation index system of ICT development level in university administrative departments

\begin{tabular}{|c|c|c|}
\hline Target & First-level indexes & Second-level indexes \\
\hline \multirow{14}{*}{$\begin{array}{l}\text { ICT development } \\
\text { level in } \\
\text { university } \\
\text { administrative } \\
\text { departments }\end{array}$} & \multirow{2}{*}{$\begin{array}{l}\text { Business process and information } \\
\text { release }\left(\mathrm{A}_{1}\right)\end{array}$} & Business process $\left(\mathrm{a}_{11}\right)$ \\
\hline & & Information release $\left(a_{12}\right)$ \\
\hline & \multirow[t]{3}{*}{ Planning and management $\quad\left(\mathrm{A}_{2}\right)$} & Informatization planning $\left(\mathrm{a}_{21}\right)$ \\
\hline & & Management system $\quad\left(\mathrm{a}_{22}\right)$ \\
\hline & & Operation management $\left(\mathrm{a}_{23}\right)$ \\
\hline & \multirow[t]{3}{*}{ Information security $\left(\mathrm{A}_{3}\right)$} & Information security codes of conduct $\left(\mathrm{a}_{31}\right)$ \\
\hline & & Information security response mechanism $\quad\left(a_{32}\right)$ \\
\hline & & Information security responsibility system $\quad\left(\mathrm{a}_{33}\right)$ \\
\hline & \multirow[t]{2}{*}{ Data construction $\left(\mathrm{A}_{4}\right)$} & Shared data ratio $\left(a_{41}\right)$ \\
\hline & & Shared data quality $\left(\mathrm{a}_{42}\right)$ \\
\hline & \multirow[t]{2}{*}{ System and website $\left(\mathrm{A}_{5}\right)$} & Information system $\left(\mathrm{a}_{51}\right)$ \\
\hline & & Website $\left(a_{52}\right)$ \\
\hline & \multirow[t]{2}{*}{ Human resource $\left(\mathrm{A}_{6}\right)$} & Informatization leading group $\left(\mathrm{a}_{61}\right)$ \\
\hline & & Informatization staff team $\quad\left(a_{62}\right)$ \\
\hline
\end{tabular}




\section{Evaluation of ICT development level in university administrative departments}

Based on the evaluation model and index system, the study carried out the evaluation of ICT development level in administrative departments of a university in China. According to the evaluation results, the study gave some suggestions for the informatization construction in the university administrative departments

\section{Samples.}

Samples gathered for this study were 33 administrative departments in a university in China except teaching and scientific research departments. A questionnaire survey was conducted on the administrative departments, and the return rate is $100 \%$.

Method.

To understand the ICT development level of the 33 departments, the study designed a questionnaire based on the evaluation model and index system.

Before the questionnaire was implemented, it was sent to experts of ICT in higher education and the administrative staff in charge of education informationization in the university. During several rounds of discussion, the experts gave some advice about the structure of the questionnaire and the measurable problems. Also many experts were consulted about the readability of the questionnaire and the effectiveness of the questions. According to the feedback, the questionnaire was modified for many times. And management staff of various departments in this university were also consulted before the questionnaire was finished.

There were 26 items in the questionnaire, which were divided into four types: single-topic selections (Questions 1-3), fill in the blanks (Questions4-7), five-point Likert scale (Questions 8-14), true or false items (Questions 15-26).

\section{Data analysis.}

In this research, the quantitative method is used to calculate the score of each management department, and the score is used as a measure standard of the ICT level. Total score is 100. The study used the method of non-dimensional convert the data to the score of each third-level indexes, and then based on the weight of each index, the study used the method of weighted summation to calculate the total score.

\section{Results}

\section{The analysis of the development of ICT level in administrative departments.}

Based on the results of the questionnaire, the average score of 33 departments was 67.73. The highest score was 94.34 while the lowest was only 28.50, indicating that there was a large gap between various departments.

In addition, in order to compare whether there were a significant differences or polarized between the administrative departments, 33 departments were sorted by the total score. And the study took the top $27 \%$ of the departments to form high-score group (HG), the bottom $27 \%$ to form low-score group (LG). Then we conducted $t$-test for all second-level indexes except the indexes of informatization planning, operation management and informatization leading group, as shown in Tab 12 . In the informatization planning, all sectors were 100, it was clear that there was no difference between HG and LG. In the operation management, the average of HG was 100, while the average of LG was 0, and it was obvious that there was a big difference between HG and LG. Similarly, in the informatization leading group, the average of HG was 100, while the average of LG was 50, and it was obvious that there was a big difference between HG and LG. 
Tab 2. Descriptive data and t-test results of second-level indexes

\begin{tabular}{|c|c|c|c|c|c|}
\hline Index & Groups & $\mathbf{N}$ & Mean & S.D. & $t$ \\
\hline \multirow[t]{2}{*}{$\mathrm{a}_{11}$} & HG & 9 & 79.31 & 12.60 & \multirow[t]{2}{*}{$12.317 * * *$} \\
\hline & LG & 9 & 12.68 & 10.24 & \\
\hline \multirow[t]{2}{*}{$a_{12}$} & HG & 9 & 100.00 & 0.00 & \multirow[t]{2}{*}{$44.228 * * *$} \\
\hline & $\mathrm{LG}$ & 9 & 7.87 & 6.25 & \\
\hline \multirow[t]{2}{*}{$a_{22}$} & HG & 9 & 100.00 & 0.00 & \multirow[t]{2}{*}{$4.00 * *$} \\
\hline & $\mathrm{LG}$ & 9 & 33.33 & 50.00 & \\
\hline \multirow[t]{2}{*}{$a_{31}$} & $\mathrm{HG}$ & 9 & 100.00 & 0.00 & \multirow[t]{2}{*}{$6.424 * * *$} \\
\hline & LG & 9 & 22.22 & 36.32 & \\
\hline \multirow[t]{2}{*}{$a_{32}$} & HG & 9 & 100.00 & 0.00 & \multirow[t]{2}{*}{$7.071 * * *$} \\
\hline & $\mathrm{LG}$ & 9 & 16.67 & 35.35 & \\
\hline \multirow[t]{2}{*}{$a_{33}$} & HG & 9 & 100.00 & 0.00 & \multirow[t]{2}{*}{$6.373 * * *$} \\
\hline & LG & 9 & 22.44 & 36.51 & \\
\hline \multirow[t]{2}{*}{$\mathrm{a}_{41}$} & HG & 9 & 83.89 & 18.67 & \multirow[t]{2}{*}{$13.479 * * *$} \\
\hline & $\mathrm{LG}$ & 9 & 0.00 & 0.00 & \\
\hline \multirow[t]{2}{*}{$a_{42}$} & HG & 9 & 88.89 & 9.93 & \multirow[t]{2}{*}{$26.854 * * *$} \\
\hline & LG & 9 & 0.00 & 0.00 & \\
\hline \multirow[t]{2}{*}{$\mathrm{a}_{51}$} & $\mathrm{HG}$ & 9 & 100.00 & 0.00 & \multirow[t]{2}{*}{$7.573 * * *$} \\
\hline & $\mathrm{LG}$ & 9 & 14.77 & 33.76 & \\
\hline \multirow[t]{2}{*}{$\mathrm{a}_{52}$} & HG & 9 & 100.00 & 0.00 & \multirow[t]{2}{*}{$8.854 * * *$} \\
\hline & LG & 9 & 61.11 & 13.17 & \\
\hline \multirow[t]{2}{*}{$a_{62}$} & $\mathrm{HG}$ & 9 & 100.00 & 0.00 & \multirow[t]{2}{*}{$35.411 * * *$} \\
\hline & LG & 9 & 28.21 & 6.08 & \\
\hline
\end{tabular}

The table above showed the $t$-test results of second-level indexes. In the management system, HG was significantly higher than that of LG $(t=4.00, p=0.001<0.01)$, and in other indexes, HG was also significantly higher than LG $(t>0, p=0.000<0.001)$. Thus, departments of LG need to be strengthened in all aspects of the development of ICT level.

The analysis of each index's development differences in different dimensions.

Figure 2 showed the average scores of all the departments in the five first-level indexes, and the score of planning and management was the highest, which was 85.88, indicating that the development of the planning and management was the best. Analysis of the questionnaire showed that all departments had a good understanding of the planning of ICT in higher education, and thought that the planning of ICT was very helpful to the business. $72.73 \%$ departments have already developed the information management system, $60.60 \%$ of the departments had professional and technical personnel to maintain the information system. In contrast, the ICT development level in the data construction was poor, which the average score was 28.7, because the ratio of the data sharing in each department was relatively low. Only $27.27 \%$ of the departments realized the data sharing.

The analysis of related factors.

The study performed a Spearman correlation analysis to understand the correlation between the second-level indexes and the development level of the management informatization, as well as the interaction between the all second-level indexes.

(a) Correlation analysis between the second-level indexes and the development level of ICT in the management departments

As shown in Tab 13, by analyzing the correlation of ICT development level and the second-level indexes, it was found that ICT development level had significant correlation with most indexes except the four indexes including information release, informatization planning, website and informatization leading group. And ICT development level had more significant correlation with these indexes including business process, management system, operating management, information security codes of conduct, information system, information security responsibility system, shared data ratio and informatization staff team $(r>0, p<0.01)$ than the indexes including the quality of 
shared data and information security responsibility mechanism $(r>0, p<0.05)$.

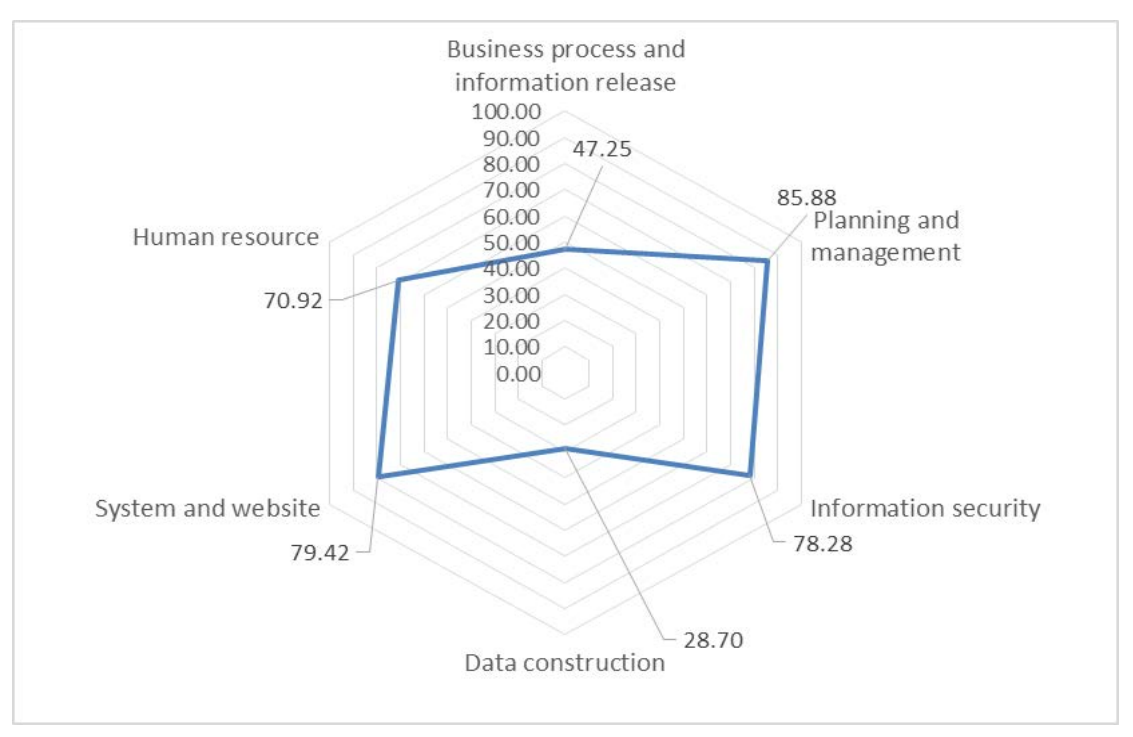

Fig 2. The average score of the first-level indexes

Tab 3.Spearman correlation between the second-level indexes and the ICT development level in university administrative departments

\begin{tabular}{|c|c|c|c|}
\hline Indexes & N & $\mathbf{r}$ & P \\
\hline $\mathrm{a}_{11}$ & 33 & $.729^{* *}$ & .000 \\
\hline $\mathrm{a}_{12}$ & 33 & .201 & .261 \\
\hline $\mathrm{a}_{21}$ & 33 &. $\mathrm{a}$ & .000 \\
\hline $\mathrm{a}_{22}$ & 33 & $.668^{* *}$ & .000 \\
\hline $\mathrm{a}_{23}$ & $.703^{* *}$ & .003 \\
\hline $\mathrm{a}_{31}$ & 33 & $.508^{* *}$ & .009 \\
\hline $\mathrm{a}_{32}$ & 33 & $.446^{* *}$ & .021 \\
\hline $\mathrm{a}_{33}$ & 33 & $.401^{*}$ & .003 \\
\hline $\mathrm{a}_{41}$ & 33 & $.501^{* *}$ & .017 \\
\hline $\mathrm{a}_{42}$ & 33 & $.414^{*}$ & .009 \\
\hline $\mathrm{a}_{51}$ & 33 & $.449^{* *}$ & .084 \\
\hline $\mathrm{a}_{52}$ & 33 & .305 & .614 \\
\hline $\mathrm{a}_{61}$ & 33 & -.091 & .001 \\
\hline $\mathrm{a}_{62}$ & 33 & $.562^{* *}$ & $* 0.00$ \\
\hline
\end{tabular}

(b) Correlation analysis between the second-level indexes

As shown in Tab 4, by analyzing the correlation between the secondary-level indexes, we found that the indexes of business process, ratio of shared data and quality of shared data, the indexes of management system, operating management, information security codes of conduct, information security response mechanism, information security responsibility system, the indexes of operating management, informatization staff team and information system had significant correlation ( $\mathrm{r}>0$, $\mathrm{p}<0.01)$. The indexes of information security codes of conduct, information security response mechanism and information security responsibility system were significantly related $(r>0, p<0.01)$. The indexes of business process, management system, operating management, information system and informatization staff team were significantly related $(r>0, p<0.05)$. The indexes of information release, department websites, informatization leading group were significantly related $(r>0, p<0.05)$. The indexes of operating management, information security responsibility system and the ratio of shared data, the indexes of information security codes of conduct and information security responsibility system were significantly related $(r>0, p<0.05)$. 
Tab 4.Spearman Correlation analysis between the second-level indexes

\begin{tabular}{|c|c|c|c|c|c|c|c|c|c|c|c|c|c|c|}
\hline Indexes & $\mathbf{a}_{11}$ & $\mathbf{a}_{12}$ & $\mathbf{a}_{21}$ & $\mathbf{a}_{22}$ & $\mathbf{a}_{23}$ & $\mathbf{a}_{31}$ & $\mathbf{a}_{32}$ & $\mathbf{a}_{33}$ & $\mathbf{a}_{41}$ & $\mathbf{a}_{42}$ & $\mathbf{a}_{51}$ & $\mathbf{a}_{52}$ & $\mathbf{a}_{61}$ & $\mathbf{a}_{62}$ \\
\hline$a_{11}$ & - & - & - & $\begin{array}{l}r=0.368 \\
p=0.035\end{array}$ & $\begin{array}{l}r=0.440 \\
p=0.010\end{array}$ & - & - & - & $\begin{array}{l}r=0.531 \\
p=0.001\end{array}$ & $\begin{array}{l}r=0.519 \\
p=0.002\end{array}$ & $\begin{array}{l}r=0.366 \\
p=0.036\end{array}$ & - & $\mathrm{v}$ & $\begin{array}{l}r=0.397 \\
p=0.022\end{array}$ \\
\hline$a_{12}$ & - & - & - & - & - & - & - & - & - & - & - & $\begin{array}{l}r=0.385 \\
p=0.027\end{array}$ & $\begin{array}{l}\mathrm{r}=0.345 \\
\mathrm{p}=0.049\end{array}$ & - \\
\hline$a_{21}$ & - & - & - & - & - & - & - & - & - & - & - & - & - & - \\
\hline$a_{22}$ & - & - & - & - & $\begin{array}{l}\mathrm{r}=0.585 \\
\mathrm{p}=0.000\end{array}$ & $\begin{array}{l}r=0.507 \\
p=0.003\end{array}$ & $\begin{array}{l}\mathrm{r}=0.487 \\
\mathrm{p}=0.004\end{array}$ & $\begin{array}{l}r=0.507 \\
p=0.003\end{array}$ & & & & & & \\
\hline$a_{23}$ & - & - & - & - & - & - & - & - & $\begin{array}{l}\mathrm{r}=0.396 \\
\mathrm{p}=0.023\end{array}$ & - & $\begin{array}{l}\mathrm{r}=0.437 \\
\mathrm{p}=0.011\end{array}$ & - & - & $\begin{array}{l}\mathrm{r}=0.686 \\
\mathrm{p}=0.000\end{array}$ \\
\hline$a_{31}$ & - & - & - & - & - & - & $\begin{array}{l}\mathrm{r}=0.397 \\
\mathrm{p}=0.022\end{array}$ & $\begin{array}{l}r=0.525 \\
p=0.002\end{array}$ & - & - & - & - & - & - \\
\hline$a_{32}$ & - & - & - & - & - & - & - & $\begin{array}{l}r=0.680 \\
p=0.000\end{array}$ & - & - & - & - & - & - \\
\hline $\mathrm{a}_{33}$ & - & - & - & - & - & - & - & - & - & - & - & - & - & - \\
\hline $\mathrm{a}_{41}$ & - & - & - & - & - & - & - & - & - & $\begin{array}{l}\mathrm{r}=0.778 \\
\mathrm{p}=0.000\end{array}$ & $\begin{array}{l}\mathrm{r}=0.377 \\
\mathrm{p}=0.030\end{array}$ & - & - & $\begin{array}{l}\mathrm{r}=0.408 \\
\mathrm{p}=0.018\end{array}$ \\
\hline $\mathrm{a}_{42}$ & - & - & - & - & - & - & - & - & - & - & - & - & - & - \\
\hline $\mathrm{a}_{51}$ & - & - & - & - & - & - & - & - & - & - & - & - & - & - \\
\hline$a_{52}$ & - & - & - & - & - & - & - & - & - & - & - & - & - & - \\
\hline $\mathrm{a}_{61}$ & - & - & - & - & - & - & - & - & - & - & - & - & - & - \\
\hline $\mathrm{a}_{62}$ & - & - & - & - & - & - & - & - & - & - & - & - & - & - \\
\hline
\end{tabular}

\section{Discussion}

The results showed that the gap between ICT development level in different administrative departments was large. In addition to the informatization planning, the study found that there were significant differences between HG and LG in other second-level indexes and the polarization was serious. According to analyzing departments which have greater differences in the ICT development level, the study found that most of the departments in HG were the departments that serving for student and propaganda, while most of the departments in LG were comprehensive administrative departments. It indicated that the ICT development level in university administrative departments was unbalanced seriously, the ICT development level in the departments for student services and propaganda was better than in the comprehensive management departments. From the comprehensive development of management informatization in the university, the study recommend that the university need to strengthen the ICT construction in comprehensive administrative departments furtherly, and reasonably conduct plan and balanced resource allocation to develop ICT construction in the administrative departments.

From the average score of all departments in the first dimension, we can find that the ICT development level of the university was low in two aspects involved in business process and information release and data construction. By analyzing the correlation between each second-level index and ICT development level, the study found that there was a significant correlation among the ICT development level and business processes, shared data ratio and shared data quality. It can be speculated that the main reason caused the low development level of ICT in business processes and information release and data construction was the low development level of ICT in business processes, shared data ratio, shared data quality. Through the analysis of the correlation between the second-level indexes, it was found that the business process of management was significantly related to the shared data ratio and the data quality. Data construction was the important prerequisite for the realizing informatization of management business process. From results of the survey, the important reason for the low level of business process informatization was the low level of data construction. Therefore, in order to promote the development and improvement of ICT in university administrative departments, we suggested that the university need to strengthen the data construction to promote the management business process informatization including the ratio and quality of shared data. 


\section{Conclusion}

The purpose of this study was to understand the characteristics and shortcomings of the university management informatization, and then based on the problems in the development of university management informatization to propound some corresponding suggestions. The study constructed an evaluation model and index system about the ICT development level of university administrative departments, and used the evaluation index system to carry out the evaluation and analysis of ICT development level in 33 administrative departments in a university in China. The study found that the poor data construction led to the lack of support for the business process informatization in administrative departments. Thus it affected the overall level of ICT development level in administrative departments. And the big difference between different administrative departments in the ICT development level also showed that the university management informatization was not balanced. Therefore, the university needs to strengthen the data construction and promote the business process informatization by increasing the proportion of shared data and improving the quality of the shared data. The evaluation of ICT development level in university administrative departments can reveal the problems existing in management informatization in university, which is conducive to adjust the informatization planning and strategy timely, and promote the ICT development level in universities reasonably and efficiently.

\section{Acknowledgement}

We thank all participants. This study is supported by the National Key Technology Research and Development Program (Project NO. 2014BAH22F01).

\section{References}

[1] Lu C, Tsai C C, Wu D. The role of ICT infrastructure in its application to classrooms: A large scale survey for middle and primary schools in China [J]. Educational Technology \& Society, 2015, 18(2):249-261.

[2] Zhang J, Fang Y, Ma X. The latest progress report on ICT application in Chinese basic education [J]. British Journal of Educational Technology, 2010, 41(4):567-573.

[3] Yang J, Huang X, Liu X. An analysis of education inequality in China [J]. International Journal of Educational Development, 2014, 37(4):2-10.

[4] [5] [20] Duan W, Liu S. A study on the Evaluation Model of the Higher Education Informatization[C]// International Conference on Future Information Technology and Management Engineering. 2010:321-325.

[6] Yang J Y, Xiong Y D. The World Summit on the information society, "ICT core indexes report" -- three of the series report on informatization statistical evaluation research [J]. China information industry, 2010, (10): 67 - 72.

[7] International Tele-communication Union. Partnership on measuring ICT for development-core ICT indicators [M]. Geneva:8.2010.

[8] The 2004 National. Survey of Information Technology in US Higher Education. [EB/OL]. [2016-6-22].http://www.campus computing.net.AccessedApt.102005.

[9] EDUCAUSE. About EDUCAUSE [EB/OL]. [2016-6-22].

http: //www.educause.edu/membership.

[10]Chen J, Zhao X. The core issues of the ten major IT issues in EDUCAUSE [J]. China Education Informatization: Higher education and Vocational education, 2015,(11): 16-19. 
[11]EDUCAUSE. Top 10 IT Issues, 2016: Divest, Reinvest, and Differentiate [EB/OL]. [2016-4-12].http://er.educause.edu/articles/2016/1/top-10-it-issues-2016

[12]EDUCAUSE. EDUCAUSE Top-10 IT Issues Lists [EB/OL]. [2016-4-12].https://net.educause.edu/ir/library/pdf/Top10ITIssuesbyCClass.pdf.

[13]Qin $\mathrm{J} \mathrm{H}, \mathrm{Xu} \mathrm{X}, \mathrm{Su} \mathrm{X} \mathrm{N}, \mathrm{A}$ study on the evaluation index system of university informatization[J]. Modern library and information technology.2006, (4): 63-69.

[14]2003 Annual College Information Questionnaire [EB/OL]. [2016-4-10].

http: //147. 8. 151. 111 /research/hku/2003survey/Questionnare.pdf ( Accessed Apr. 30,2005)

[15]Zhao G D, Wang Q, A comparative study on the development of informatization in Colleges and universities in China, the United States and Hongkong [J]. Modern Distance Education Research, 2003, (2): 12-18

[16] Zhang C H, Gao Y, Shen H B, Zhu Y H, Yan H. A study on the evaluation index system of informatization in Colleges and universities [J]. Educational informatization .2003,(12),:45-47.

[17]An B S, Zhong K D,Discussion about China's higher school informatization evaluation index system construction of theory[J]. China Educational Technology.2004, (4):24-27..

[18]Jiang D X, Mi Y, Guo Q S, University informatization development present situation and the policy suggestions. China Educational Technology [J]. Higher education and Vocational education.2009, (8):27-30.

[19]Wu H Y, Jiang D X, Yuan F and so on. A study on performance evaluation index system of education informatization[J]. Journal of Wuhan University: Science Edition.2012, 58 (1):48-52. 